\title{
The Exogenous Application of Non-Toxic Sulfur Contributes to the Growth-Promoting Effects of Leaf Lettuce (Lactuca sativa L. var. crispa)
}

\author{
Jong-Chan Park ${ }^{1}$, Nipin Sp ${ }^{2}{ }^{(D}$, Hyoung Do Kim ${ }^{2,3}$, Dong Young Kang ${ }^{2}$, Il Ho Kim ${ }^{3}$, Se Won Bae ${ }^{4}(\mathbb{D}$, \\ Young Yang ${ }^{2}$ and Kyoung-Jin Jang ${ }^{2, *}$ (1)
}

1 Plant Systems Engineering Research Center, Korea Research Institute of Bioscience \& Biotechnology (KRIBB), Daejeon 34141, Korea; reredfox@kribb.re.kr

2 Department of Pathology, School of Medicine, Institute of Biomedical Science and Technology, Konkuk University, Chungju 27478, Korea; nipinsp@konkuk.ac.kr (N.S.); hdkim0424@konkuk.ac.kr (H.D.K.); kdy6459@kku.ac.kr (D.Y.K.); ymyang56@gmail.com (Y.Y.)

3 Nara Bio Research \& Development Center Co., Ltd., Gunsan 54006, Jeollabuk-do, Korea; klh77241515@gmail.com

4 Department of Chemistry and Cosmetics, Jeju National University, Jeju 63243, Korea; swbae@jejunu.ac.kr

* Correspondence: jangkj@konkuk.ac.kr; Tel.: +82-2-2030-7839

check for

updates

Citation: Park, J.-C.; Sp, N.; Kim, H.D.; Kang, D.Y.; Kim, I.H.; Bae, S.W.; Yang, Y.; Jang, K.-J. The Exogenous Application of Non-Toxic Sulfur Contributes to the Growth-Promoting Effects of Leaf Lettuce (Lactuca sativa L. var. crispa). Agriculture 2021, 11, 769. https://doi.org/10.3390/ agriculture11080769

Academic Editor: Matevz Likar

Received: 1 July 2021

Accepted: 10 August 2021

Published: 12 August 2021

Publisher's Note: MDPI stays neutral with regard to jurisdictional claims in published maps and institutional affiliations.

Copyright: (c) 2021 by the authors. Licensee MDPI, Basel, Switzerland. This article is an open access article distributed under the terms and conditions of the Creative Commons Attribution (CC BY) license (https:// creativecommons.org/licenses/by/ $4.0 /)$.
Abstract: Sulfur is an essential nutrient-along with nitrogen, phosphorus, and potassium-for plant growth and development. Sulfur is mostly supplied to crops through soil fertilizers. However, chemical fertilizers are overused to increase crop yields despite environmental threats. The proper use of chemical fertilizers positively affects crop growth and yield increase. Regardless, residues from misuse threaten not only the soil ecosystem, but also the marine ecosystem. Therefore, the need to minimize chemical fertilizer abuse is imperative. This article reports that sulfur can be applied to crop leaves as nontoxic sulfur (NTS) in trace amounts to positively affect plant hormones, chloroplast content, and ROS scavenging system, thereby promoting growth, and increasing crop yields. Furthermore, NTS and microelements, the micronutrients calcium and magnesium, produced a synergistic effect when applied together, and NTS enhanced the expression of auxin and gibberellinrelated genes. Additionally, chlorophyll content was increased, and ROS scavenging ability was greatly improved. Therefore, NTS can effectively deliver potent growth-promoting functions of plants faster and safer than did soil fertilizers and consequently increase crop yield. This finding is a new strategy to replace soil chemical fertilizers in supplying sulfur. It is potentially valuable for increasing crop yields and can be applied to other crops.

Keywords: nontoxic sulfur; growth promotion; phytohormone; ROS scavenging; crop yield; leaf lettuce

\section{Introduction}

Currently, in agriculture, chemical fertilizers and pesticides are used to improve crop productivity. Their use is one of the easiest ways to optimize plant nutrition and control pests, diseases, and weeds [1]. The appropriate use of chemical fertilizers is an essential part of modern agriculture as it favors the balance of crop growth and soil nutrition $[2,3]$. However, the excessive and long-term use of chemical fertilizers can pollute the environment and deteriorate soil health [4-7]. To alleviate this problem, many farmers use organic fertilizers, which are naturally available mineral sources containing essential plant nutrients. However, improper use also leads to over-nutrition or nutrient deficiencies in the soil. Therefore, the proper control of organic fertilizers and a safer alternative to chemical fertilizers are necessary. Organic fertilizers can be obtained from many natural sources, including animal manure, slurry, blood meal, and fish-minute seaweed [8]. 
Sulfur is an important nutrient essential for plant growth, along with nitrogen, phosphorus, and potassium. Sulfur naturally exists in inorganic and organic forms, and sulfate $\left(\mathrm{SO}_{4}{ }^{2-}\right)$ is the most common form of sulfur in nature. Sulfur is mainly absorbed as sulfate from the soil and then transferred to the plastids of plant leaves to reduce sulfate to sulfide and assimilate into organic products [9-12]. Sulfur is present and is used in cells as a component of S-amino acids, chloroplasts, sulfatides, membrane sulfolipids, cell walls, vitamins, coenzymes, and prosthetic groups. Therefore, sulfur plays an essential role in biological functions, such as photosynthesis, respiration, and the structural formation of cell membranes and cell walls in plants [10-14]. In particular, proteins and compounds containing sulfur play an important role in improving resistance under biotic and abiotic stresses $[15,16]$. In addition, sulfur is closely related to crop yield and quality. The content of sulfur-containing amino acids is a very important indicator to evaluate crop quality [17-19]. For example, sulfur increases soybean yield and the dry matter of the seeds [20-22]. In wheat, the supply level of sulfur also significantly impacts flour extraction rates, gluten quality, and baking quality [23]. Sulfur is also an essential element indirectly consumed by humans. Humans can ingest sulfur in the form of food, such as onions, garlic, and duck meat [24]. Mineral sulfur that exists in nature is toxic because other substances are bound to it, and these must be removed before they can be consumed. In many countries, the nontoxic form of dietary or natural sulfur is used for medical purposes from which toxic substances have been removed [25]. Recent research studies using nontoxic sulfur (NTS) extracted from mineral sulfur are being actively conducted. It has been reported that NTS improves growth hormone signal transduction ability in mouse muscle cells [26] and has various beneficial functions, such as anticancer effect [27], antioxidant function [28], the antiketotic effect [29], and anti-inflammatory function [30-33].

The role of sulfur as a food element and its role in nutrients and fertilizers are greatly underestimated because it is believed that the sulfur present in the soil minerals is sufficient to maintain the required levels [34,35]. Recently, sulfur deficiency in arable soils in many parts of the world has become clear, and the lack of sulfur is a major constraint in producing food for human consumption. Sulfur deficiency is a major problem in the US and Asia, particularly in China, where 30\% of the land is sulfur-poor [36].

The leaf lettuce used in this study is mainly consumed as a salad food and is a vital vegetable grown in greenhouses because of its rapid growth and commercial value $[37,38]$. We investigated whether NTS as a substitute for sulfate-containing soil fertilizer in a greenhouse environment, which is a commercial cultivation site for leaf lettuce, increases yields. Therefore, the study was safely conducted rather than by directly applying NTS to the leaves, thereby sulfur-containing toxic substances. The direct application of NTS triggered the early growth-promoting effects of leaf lettuce, ultimately resulting in increased yield. Overall, our study provides a means for applying NTS to affect plant growth hormone biosynthesis and increase crop yield by maintaining healthier crop growth through increased chloroplasts and increased antioxidant enzyme activity.

\section{Materials and Methods}

\subsection{Plant Material}

Leaf lettuce (Lactuca sativa L. var. crispa cv. Chungchima) seeds were sown in gardening topsoil containing a mixture of vermiculite and peat $(3: 1, v / v)$ and germinated under $150 \mu \mathrm{mol} \mathrm{m}{ }^{-2} \mathrm{~s}^{-1}$ irradiance provided in a controlled environment. Germinated seedlings were grown for 14 days in a growth chamber and then transferred to a greenhouse. The growth chamber conditions were $60 \%$ humidity, $24^{\circ} \mathrm{C}, 150 \mu \mathrm{mol} \mathrm{m}^{-2} \mathrm{~s}^{-1}$ light intensity, and $18 \mathrm{~h}$ light and $6 \mathrm{~h}$ darkness. We started this experiment using the plants at the 3-4 leaf stage.

\subsection{NTS, Calcium, and Magnesium Materials and Experimental Design}

In this study, the experiments were conducted using NTS (Modoo-SSAK, Nara Bio, Gunsan, Korea), water-soluble calcium (Ca) ((CaO), Modoo-SSAK Calma, Nara Bio, Gun- 
san, Korea), and water-soluble magnesium (Mg) ((MgO), Modoo-SSAK Calma, Nara Bio, Gunsan, Korea). The experiment was conducted by dividing the plants into four groups, namely, nontreatment group (NT), NTS alone treatment group (NTS), $\mathrm{CaO} / \mathrm{MgO}$ treatment group $(\mathrm{CaO} / \mathrm{MgO})$, and mixed (NTS, $\mathrm{CaO}$, and $\mathrm{MgO}$ ) treatment group (mix), when the second leaf of the lettuce plants was fully expanded and the third to fourth leaf appeared. The groups have treated a total of four times at one-week intervals. The treatment concentrations were $0.8 \mathrm{mg} \mathrm{mL}^{-1} \mathrm{NTS}, 0.12 \mathrm{mg} \mathrm{mL}^{-1} \mathrm{CaO}$, and $0.05 \mathrm{mg} \mathrm{mL}^{-1} \mathrm{MgO}$, and $5 \mathrm{~mL}$ was sprayed per plant.

\subsection{Physiological Analysis}

Plants were sampled one week after each treatment, harvested 42 days after planting, and then immediately divided into shoot tissue (leaves and stem) and roots. After their sizes and number of leaves were measured, all samples were kept in a dry oven at $60^{\circ} \mathrm{C}$ for a week, and dry weight was measured.

\subsection{RNA Extraction and Quantitative Real-Time RT-PCR}

Total RNA was extracted from lettuce leaves using the NucleoSpin RNA Plant Kit (Macherey-Nagel, Düren, Germany) following the manufacturer's instructions and quantified using a NanoDrop 2000 Spectrophotometer (Thermo Fisher Scientific, Waltham, MA, USA). A single-strand cDNA was synthesized from $5 \mu \mathrm{g}$ of the extracted RNA with a SuPrimeScript cDNA Synthesis Kit (GeNet Bio, Nonsan-si, Korea) following the manufacturer's instructions. For quantitative real-time RT-PCR (qRT-PCR), a reaction mixture was prepared with $100 \mathrm{ng}$ of diluted cDNA, $5 \mu \mathrm{L}$ of $2 \times$ Prime Q-Mastermix SYBR Green I (GeNet Bio, Nonsan-si, Korea), and 10 pmol of each gene-specific primer in a final volume of $10 \mu \mathrm{L}$. qRT-PCR was performed with a Qiagen Rotor-Gene Q qRT-PCR Cycler (Qiagen, Hilden, Germany). The relative quantification of gene expression was determined using the $2^{-\Delta \Delta C t}$ method [39]. LsActin was used as the reference gene. The experiments were replicated three times, and the average expression value was calculated. The gene-specific primers are listed in Table S1.

\subsection{Chlorophyll and Carotenoid Determination}

The contents of chlorophyll $a$ and $b$ and carotenoids were determined according to Lichtenthaler and Wellburn [40]. The samples were excised from the leaves of four plants at a similar position for each treatment group. Two leaves of $100 \mathrm{mg}$ fresh weight were placed in $5 \mathrm{~mL}$ of $80 \%(v / v)$ acetone (Junsei, Tokyo, Japan). After filtration, the optical density was measured with a UV-1800 spectrophotometer (Shimadzu, Kyoto, Japan) at 663, 645 , and $440 \mathrm{~nm}$. The pigment levels were calculated using the following equations:

$$
\begin{gathered}
\text { Total chlorophyll }\left(\mathrm{mg} \mathrm{g}^{-1}\right)=20.2 \times \mathrm{OD}_{645}+8.05 \times \mathrm{OD}_{663} \\
\text { Chlorophyll a }\left(\mathrm{mg} \mathrm{g}^{-1}\right)=12.7 \times \mathrm{OD}_{663}-2.69 \times \mathrm{OD}_{645} \\
\text { Chlorophyll b }\left(\mathrm{mg} \mathrm{g}^{-1}\right)=22.9 \times \mathrm{OD}_{645}-4.68 \times \mathrm{OD}_{663} \\
\text { Carotenoids }\left(\mathrm{mg} \mathrm{g}^{-1}\right)=4.7 \times \mathrm{OD}_{440}-\left(1.38 \times \mathrm{OD}_{663}+2.69 \times \mathrm{OD}_{645}\right)
\end{gathered}
$$

\subsection{Measurement of Transient Chlorophyll a Fluorescence}

Chlorophyll fluorescence was measured from the longest leaves at their apex, middle, and base regions using the HANDY PEA fluorimeter (Hansatech, King's Lynn, UK). Before all measurements, leaves were dark-adapted for $30 \mathrm{~min}$. Light intensity was $3500 \mu \mathrm{mol}$ photons $\mathrm{m}^{-2} \mathrm{~s}^{-1}$, provided by an array of three high-intensity light-emitting diodes, focused on a spot of $5 \mathrm{~mm}$ in diameter and recorded for $1 \mathrm{~s}$ with 12-bit resolution. The HANDY PEA software (version 1.31) obtained the fluorescence parameters $\mathrm{F}_{0}, \mathrm{~F}_{\mathrm{m}}, \mathrm{F}_{\mathrm{v}}$, and $\mathrm{F}_{\mathrm{m}}$. The maximum efficiency of PSII was estimated using the equation $F_{v} / F_{m}=\left(F_{m}-F_{0}\right) / F_{m}[41,42]$. 


\subsection{Hydrogen Peroxide Determination}

One gram of lettuce leaves was homogenized in $3 \mathrm{~mL}$ of $100 \mathrm{mM}$ potassium phosphate buffer ( $\mathrm{pH}$ 7.5, Junsei, Tokyo, Japan) to determine $\mathrm{H}_{2} \mathrm{O}_{2}$ content. The homogenate was filtered through four layers of cheesecloth, centrifuged at $14,000 \times \mathrm{g}$ for $20 \mathrm{~min}$ at $4{ }^{\circ} \mathrm{C}$; then, the $\mathrm{H}_{2} \mathrm{O}_{2}$ content in the supernatant was measured. The reaction mixture contained $100 \mathrm{mM}$ potassium phosphate buffer ( $\mathrm{pH}$ 7.5), $1 \mathrm{M}$ potassium iodide (Sigma-Aldrich, St. Louis, MO, USA), and $0.1 \%$ trichloroacetic acid (Sigma-Aldrich, St. Louis, MO, USA). The reaction mixture was incubated for $1 \mathrm{~h}$ in darkness, and the absorbance was measured at $390 \mathrm{~nm}$ [43]. The $\mathrm{H}_{2} \mathrm{O}_{2}$ content in each sample was quantified with absorbance at $390 \mathrm{~nm}$ based on an equation from the $\mathrm{H}_{2} \mathrm{O}_{2}$ calibration curve.

\subsection{Antioxidant Enzyme Activity Assay}

\subsubsection{Enzyme Extraction}

For the SOD, CAT, and GR activity assay, total proteins were extracted from $1 \mathrm{~g}$ of lettuce leaves by homogenization in $100 \mathrm{mM}$ potassium phosphate buffer $(\mathrm{pH} 7.8)$ containing $0.1 \mathrm{mM}$ EDTA (Sigma-Aldrich, St. Louis, MO, USA), 1\% w/v polyvinylpyrrolidone (SigmaAldrich, USA), and $0.5 \% v / v$ Triton X-100 (Sigma-Aldrich, USA) at $4{ }^{\circ} \mathrm{C}$. The homogenate was filtered through four layers of cheesecloth and centrifuged at 14,000 $\times g$ for $25 \mathrm{~min}$ at $4{ }^{\circ} \mathrm{C}$. The total protein content was determined according to the Bradford method [44].

\subsubsection{Determination of SOD Activity}

SOD activity was measured using the method of Beyer and Fridovich [45]. Forty microliters of the protein extract were mixed with $50 \mathrm{mM}$ potassium phosphate $(\mathrm{pH} 7.8$, $9.9 \mathrm{mM}$ methionine (Sigma-Aldrich, St. Louis, MO, USA), $57 \mu \mathrm{M}$ nitroblue tetrazolium (Sigma-Aldrich, USA)), and the reaction was initiated by light illumination. One unit of SOD was defined as the amount of enzyme that causes a 50\% inhibition of the SODinhibitable NBT reduction.

\subsubsection{Determination of CAT Activity}

CAT activity was measured using the method of Aebi [46]. The reaction mixture contained $50 \mathrm{mM}$ potassium phosphate buffer ( $\mathrm{pH} 7.0)$ and $40 \mu \mathrm{L}$ protein extract. The reaction was initiated by adding $10 \mathrm{mM} \mathrm{H}_{2} \mathrm{O}_{2}$ (Junsei, Tokyo, Japan), and activity was measured as the rate of $\mathrm{H}_{2} \mathrm{O}_{2}$ decomposition (extinction coefficient, $39.4 \mathrm{mM} / \mathrm{L} \mathrm{cm}^{-1}$ ) calculated using the absorbance change at $240 \mathrm{~nm}$.

\subsubsection{Determination of GR Activity}

GR activity was measured using the method of Rao et al. [47]. The reaction mixture contained $100 \mathrm{mM}$ potassium phosphate buffer ( $\mathrm{pH} 7.8$ ), $2 \mathrm{mM}$ EDTA, $0.5 \mathrm{mM}$ GSH (oxidized form, GSSG, Sigma-Aldrich, USA), and $1 \mathrm{~mL}$ protein extract. The reaction was initiated by adding $0.2 \mathrm{mM} \beta$-nicotinamide adenine dinucleotide phosphate (NADPH, Rosche, Switzerland) at $25^{\circ} \mathrm{C}$. The activity was measured as the oxidation of NADPH (extinction coefficient, $6.2 \mathrm{mM} \mathrm{cm}^{-1}$ ) at $340 \mathrm{~nm}$.

\subsection{Statistical Analysis}

The differences between data points were statistically analyzed using analysis of variance (ANOVA), followed by Tukey's test. Statistical significance was set at $p<0.05$ using the SPSS software (version 22).

\section{Results}

\subsection{Treatment with NTS, $\mathrm{Ca}$, and $\mathrm{Mg}$ Promotes Growth in Leaf Lettuce}

We examined the effects of NTS, Ca, and Mg on promoting growth in leaf lettuce. Two weeks after the leaf lettuce germinated, treatment was performed four times in total, and phenotypic and physiological data were collected one week after each treatment. We observed that the phenotype was changed during the NTS, $\mathrm{CaO} / \mathrm{MgO}$, and mix 
(NTS/CaO/MgO) treatment period over four times compared with the nontreatment group (Figure 1A). One week after the first to the fourth treatment of the leaf lettuce, each treatment group showed an increased leaf length compared with the nontreatment group (first treatment, $24-40 \%$; second treatment, $18-34 \%$; third treatment, 3-11\%; fourth treatment, 9-26\%). In particular, one week after the first treatment for seedling, the NTS treatment group showed a high increase in leaf length $(40.77 \%)$ compared with the nontreatment group ( $\mathrm{CaO} / \mathrm{MgO}$ treatment group, $24.77 \%$; mixed treatment group, 34.06\%). In addition, one week after the second treatment, the $\mathrm{CaO} / \mathrm{MgO}$ treatment group showed a high increase in leaf length (34.26\%) compared with the nontreatment group (NTS treatment group, $18.91 \%$; mixed treatment group, 19.10\%) (Figure 1B). One week after the first to fourth treatment for leaf lettuce, compared with the nontreatment group, each treatment group showed an increased leaf width (first treatment, $32-43 \%$; second treatment, 3-8\%; third treatment, $23-50 \%$; fourth treatment, $22-39 \%$ ). In particular, one week after the first treatment for seedling, the NTS treatment group showed a high increase in leaf width $(43.3 \%)$ compared with the nontreatment group $(\mathrm{CaO} / \mathrm{MgO}$ treatment group, $32.28 \%$; mixed treatment group, 36.22\%) (Figure 1C). One week after the first to fourth treatment for leaf lettuce, compared with the nontreatment group, each treatment group showed an increased root length (first treatment, 35-44\%; second treatment, 3-245\%; third treatment, 58-104\%; fourth treatment, 141-205\%). In particular, after the second treatment, the root length was dramatically increased by $245 \%$ in the mixed treatment group compared with the nontreatment group (Figure 1D). We observed that each treatment group increased the total length (first treatment, $11-18 \%$; second treatment, $8-18 \%$; third treatment, $3-9 \%$; fourth treatment, 14-28\%), the number of leaves (first treatment, 33-53\%; second treatment, $1-21 \%$; third treatment, $11-19 \%$; fourth treatment, 37-73\%), and dry weight (first treatment, 22-50\%; second treatment, $24-55 \%$; third treatment, $27-103 \%$; fourth treatment, $106-280 \%$ ) compared with the nontreatment group (Figure 1E-G). These results suggest that NTS plays a key role in the seedling stage in increasing leaf length, width, and root length. Then, NTS exerts a synergistic effect with $\mathrm{Ca}$ and $\mathrm{Mg}$ to ultimately increase biomass.

\subsection{Treatment with NTS, Ca, and Mg Induced the Biosynthesis-Related mRNA Expression of Auxin and GA in Leaf Lettuce}

We observed the leaf and root development in the NTS, $\mathrm{CaO} / \mathrm{MgO}$, and mixed treatment groups in the seedling stage of leaf lettuce (Figure 1). We performed qPCR using samples $12 \mathrm{~h}$ after each treatment at the five-leaf stage to verify the expression of auxin and GA biosynthesis-related genes. In the case of auxin, the expression of ILR1 (NTS treatment, 1.47-fold; $\mathrm{CaO} / \mathrm{MgO}$ treatment, 1.45-fold; mixed treatment, 1.38-fold) and IAR1 (NTS treatment, 2.20-fold; $\mathrm{CaO} / \mathrm{MgO}$ treatment, 1.92-fold; mixed treatment, 2.11-fold), which are auxin biosynthesis-related genes, increased compared with the nontreatment group. In addition, the expression of the ARF2B (NTS treatment, 2.69-fold; $\mathrm{CaO} / \mathrm{MgO}$ treatment, 1.47-fold; mixed treatment, 2.94-fold) and ARF9 (NTS treatment, 1.2-fold; mixed treatment, 1.35 -fold), which are auxin-responsive genes, increased, but the expression of the ARF18 was not increased compared with the nontreatment group (Figure 2A). In the case of GA, the expression of CPS (NTS treatment, 1.43-fold; $\mathrm{CaO} / \mathrm{MgO}$ treatment, 1.23-fold; mixed treatment, 1.37 -fold), KS (NTS treatment, 1.48 -fold; $\mathrm{CaO} / \mathrm{MgO}$ treatment, 1.77-fold; mixed treatment, 2.38-fold), $\mathrm{KO}$ (NTS treatment, 1.57-fold; $\mathrm{CaO} / \mathrm{MgO}$ treatment, 1.47-fold; mixed treatment, 1.52-fold), $\mathrm{KO} 2$ (NTS treatment, 2.29-fold; $\mathrm{CaO} / \mathrm{MgO}$ treatment, 2.08-fold; mixed treatment, 3.31-fold), and GA20ox (NTS treatment, 5.54-fold; $\mathrm{CaO} / \mathrm{MgO}$ treatment, 4.18-fold; mixed treatment, 10.01-fold), which are GA biosynthesis-related genes, was increased compared with the nontreatment group (Figure 2B). These results describe that exogenous NTS, $\mathrm{Ca}$, and Mg supply induce the biosynthesis of auxin and GA. 
A

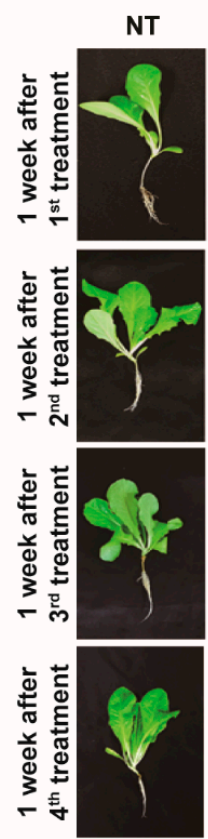

B
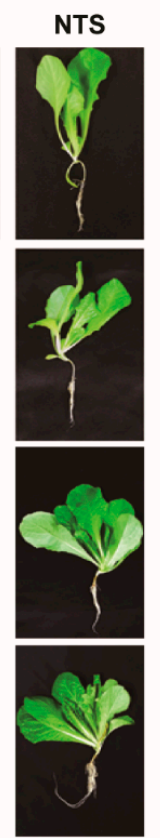


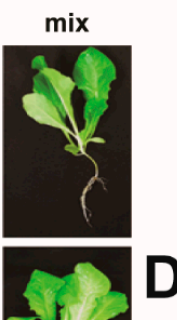

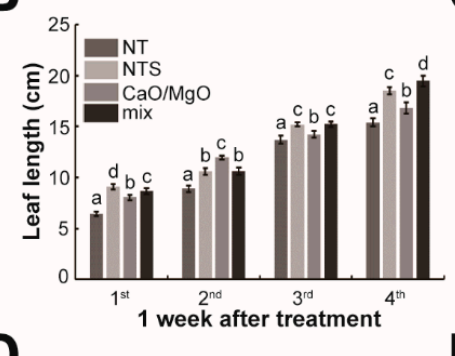

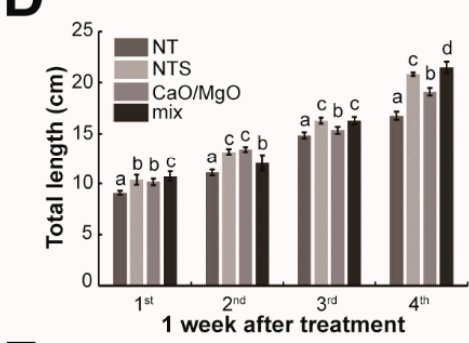

E

C
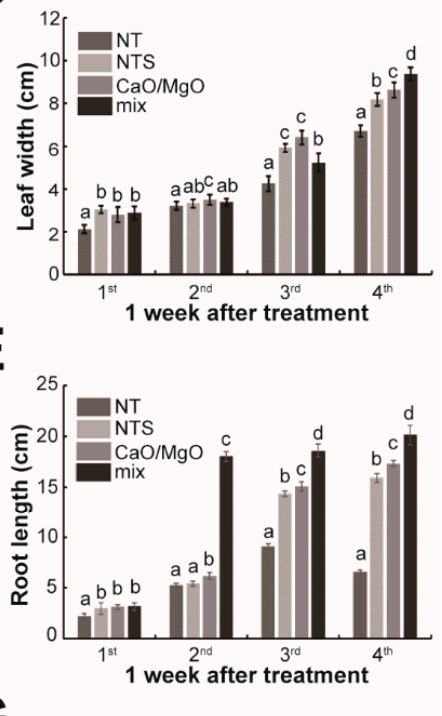

$\mathbf{G}$

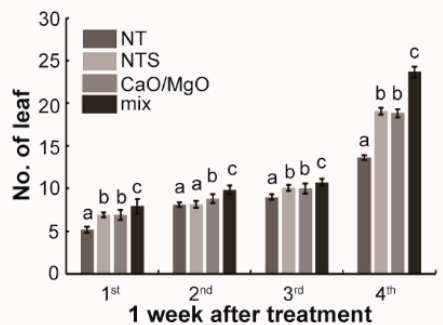

Figure 1. Effect of NTS, $\mathrm{CaO} / \mathrm{MgO}$, and mixed treatment on the morphological and physiological changes of leaf lettuce. Representative image showing phenotype changed during NTS (A), $\mathrm{CaO} / \mathrm{MgO}$, and mixed treatment. Physiological changes were measured by leaf length (B), leaf width (C), root length (D), total length (E), leaf number (F), and dry weight (G). NT, nontreatment group; NTS, NTS treatment group; $\mathrm{CaO} / \mathrm{MgO}, \mathrm{CaO} / \mathrm{MgO}$ treatment group; mix, mixed (NTS, $\mathrm{CaO}$, and $\mathrm{MgO}$ ) treatment group. All experiments were repeated three times, and the error bars indicate standard deviation $(n=12)$. Different letters above bars indicate statistically significant differences as determined by one-way ANOVA $(p<0.05)$.

A

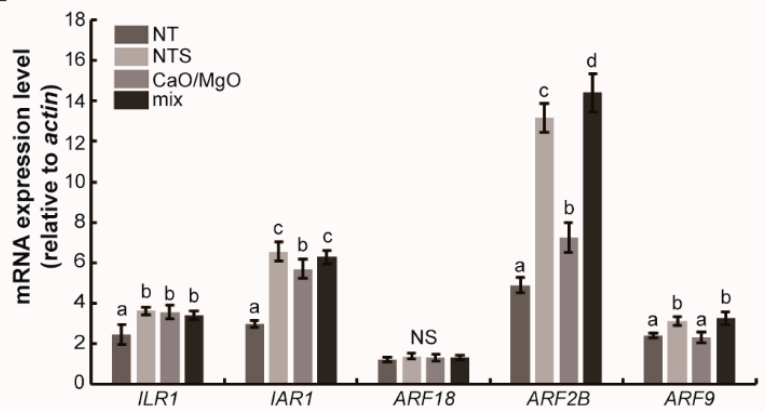

B



Figure 2. Changes in the expression of auxin biosynthesis/response genes (A) and GA biosynthesis genes (B) in leaf lettuce leaves treated with NTS, $\mathrm{CaO} / \mathrm{MgO}$, and mixed treatment. NT, nontreatment group; NTS, NTS treatment group; $\mathrm{CaO} / \mathrm{MgO}$, $\mathrm{CaO} / \mathrm{MgO}$ treatment group; mix, mixed (NTS, $\mathrm{CaO}$, and $\mathrm{MgO}$ ) treatment group. All experiments were repeated three times, and the error bars indicate standard deviation $(n=9)$. Different letters above bars indicate statistically significant differences as determined by one-way ANOVA $(p<0.05)$.

\subsection{Treatment with NTS, Ca, and Mg Changed the Photosynthetic Pigment Content in Leaf Lettuce}

After the third treatment, we observed that the leaf color in the NTS, $\mathrm{CaO} / \mathrm{MgO}$, and mixed treatment groups were darker green compared with the nontreatment group (NT) 
(Figure 1A). Therefore, we measured the leaf photosynthetic pigment content (chlorophyll $\mathrm{a}$, chlorophyll b, total chlorophyll, and carotenoids) at the harvest stage of leaf lettuce. The total chlorophyll contents were increased in all treatment groups (5-12\%); the content of chlorophyll a (5-17\%) was particularly increased. The content of chlorophyll $b$ increased in the $\mathrm{CaO} / \mathrm{MgO}$ treatment group ( $8 \%$ ), but decreased in the NTS and mixed treatment groups $(-4-6 \%)$, and there was no significant change in the carotenoid content (Figure 3A-D). These results describe that exogenous NTS, Ca, and Mg supply increase the level of physiological parameters.

A

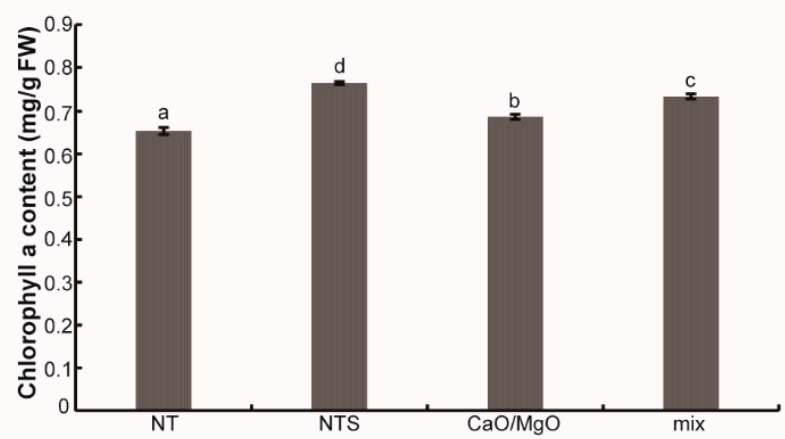

C



B

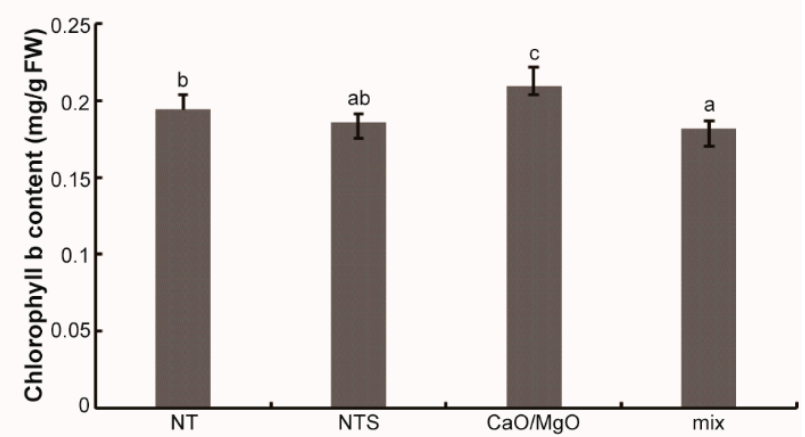

D



Figure 3. Measurement of chlorophyll and carotenoid in leaf lettuce leaves at one week after the fourth treatment. Chlorophyll a content (A), chlorophyll b content (B), total chlorophyll content (C), and carotenoid content (D) in leaf lettuce leaves. NT, nontreatment group; NTS, NTS treatment group; $\mathrm{CaO} / \mathrm{MgO}, \mathrm{CaO} / \mathrm{MgO}$ treatment group; mix, mixed (NTS, $\mathrm{CaO}$, and $\mathrm{MgO}$ ) treatment group. All experiments were repeated three times, and the error bars indicate standard deviation $(n=9)$. Different letters above bars indicate statistically significant differences as determined by one-way ANOVA $(p<0.05)$.

\subsection{Treatment with NTS, Ca, and Mg Changed the Chlorophyll Fluorescence Parameters in Leaf Lettuce}

We measured the change in chlorophyll fluorescence value, due to the difference in chlorophyll content. In the case of the initial fluorescence $\left(\mathrm{F}_{0}\right)$ value, it was observed that the $\mathrm{F}_{0}$ level increased in the treatment group, including NTS (14-15\%) (Figure 4A). Unlike the $F_{0}$ value, it was observed that the maximum fluorescence $\left(\mathrm{F}_{\mathrm{m}}\right)$ value increased in all treatment groups (5-15\%) (Figure $4 \mathrm{~B})$. The maximum quantum yield of PSII $\left(\mathrm{F}_{\mathrm{v}} / \mathrm{F}_{\mathrm{m}}\right) \mathrm{did}$ not significantly change because it was not a stress condition (Figure $4 \mathrm{C}$ ).

\subsection{Treatment with NTS, Ca, and Mg Improved Antioxidant Enzyme Activity in Leaf Lettuce}

The changes of $\mathrm{H}_{2} \mathrm{O}_{2}$ content in leaf lettuce leaves according to the treatment of exogenous NTS, $\mathrm{CaO} / \mathrm{MgO}$, and mixed treatment is shown in Figure $5 \mathrm{~A}$. In leaf lettuce leaves, a significant decrease in $\mathrm{H}_{2} \mathrm{O}_{2}$ was detected in the treatment group containing NTS, and the maximum decrease was reached in the NTS single treatment group. On the other hand, there was no decrease in $\mathrm{H}_{2} \mathrm{O}_{2}$ in the $\mathrm{CaO} / \mathrm{MgO}$ treatment group (Figure 5A). These results suggest that NTS can significantly reduce leaf oxidative stress. Compared with the 
nontreatment group, the total SOD activity was significantly increased in the treatment group containing NTS (85-90\%) (Figure 5B). The CAT activity increased in all treatment groups $(6-10 \%)$, but the GR activity increased only in the treatment group containing NTS $(55-62 \%)$ (Figure 5C,D). These results suggest that the increase in SOD activity should appear in the same pattern as the increase in $\mathrm{H}_{2} \mathrm{O}_{2}$ content, but it is due to the increase in antioxidant enzymes that scavenge $\mathrm{H}_{2} \mathrm{O}_{2}$, due to the supply of exogenous NTS.

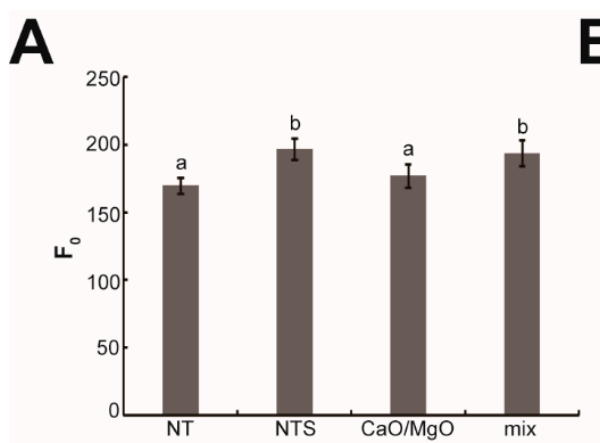

B

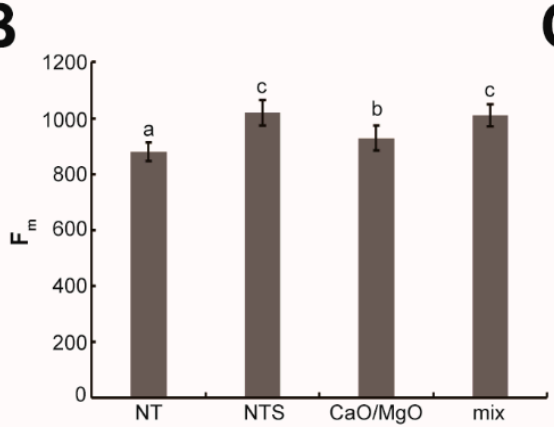

C

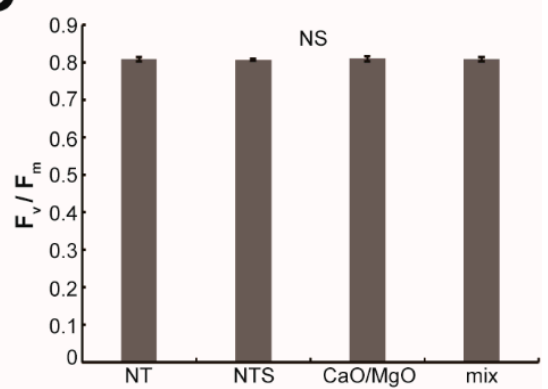

Figure 4. Measurement of chlorophyll fluorescence $\left(\mathrm{F}_{0}, \mathrm{~F}_{\mathrm{m}}\right.$, and $\left.\mathrm{F}_{\mathrm{v}} / \mathrm{F}_{\mathrm{m}}\right)$ in leaf lettuce leaves at one week after the fourth treatment. Ground fluorescence $\left(\mathrm{F}_{0}\right)$ values $(\mathrm{A})$, maximum variable fluorescence $\left(\mathrm{F}_{\mathrm{m}}\right)$ values $(\mathbf{B})$, and maximum quantum efficiency of PSII $\left(\mathrm{F}_{\mathrm{v}} / \mathrm{F}_{\mathrm{m}}\right)$ values $(\mathrm{C})$. NT, nontreatment group; NTS, NTS treatment group; $\mathrm{CaO} / \mathrm{MgO}, \mathrm{CaO} / \mathrm{MgO}$ treatment group; mix, mixed (NTS, $\mathrm{CaO}$, and $\mathrm{MgO}$ ) treatment group. All experiments were repeated three times, and the error bars indicate standard deviation $(n=12)$. Different letters above bars indicate statistically significant differences as determined by one-way ANOVA $(p<0.05)$.

A

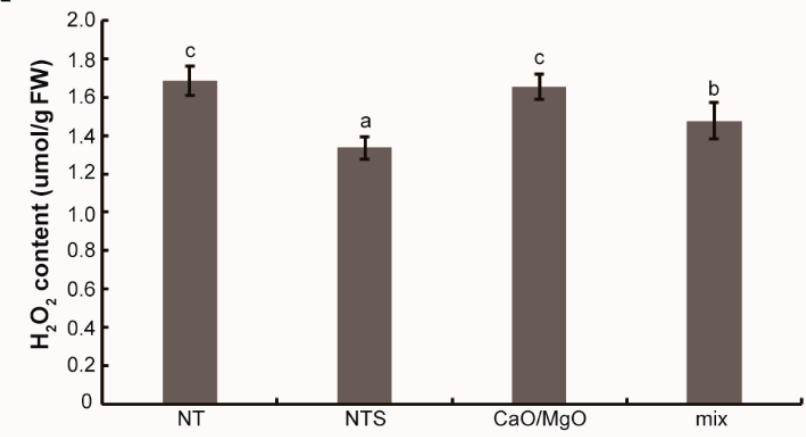

C

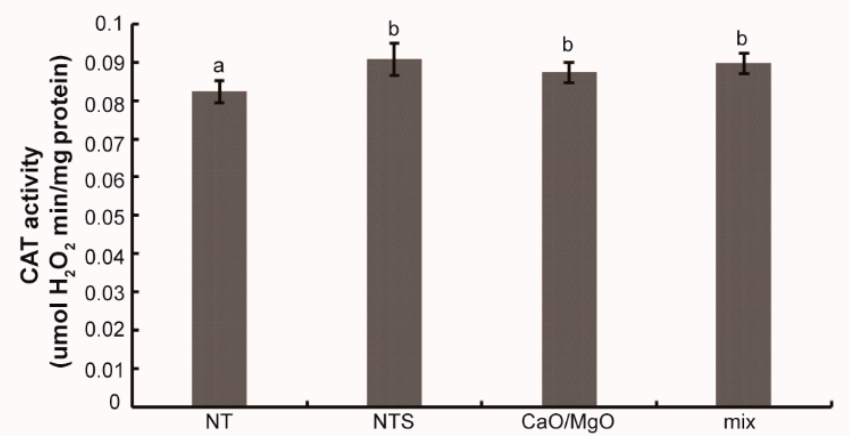

B

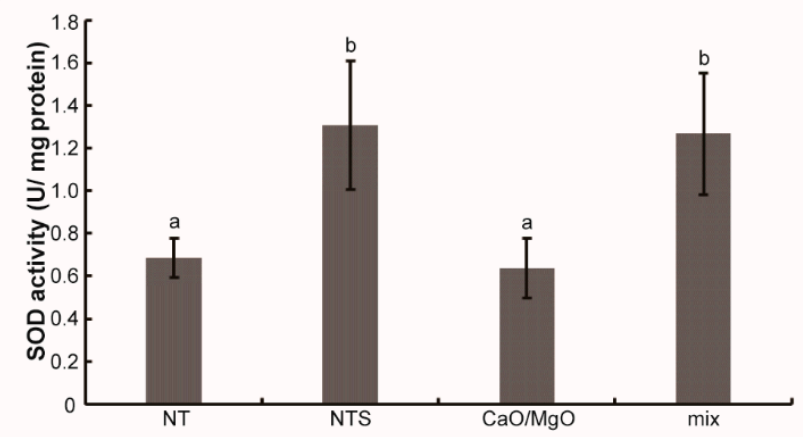

D

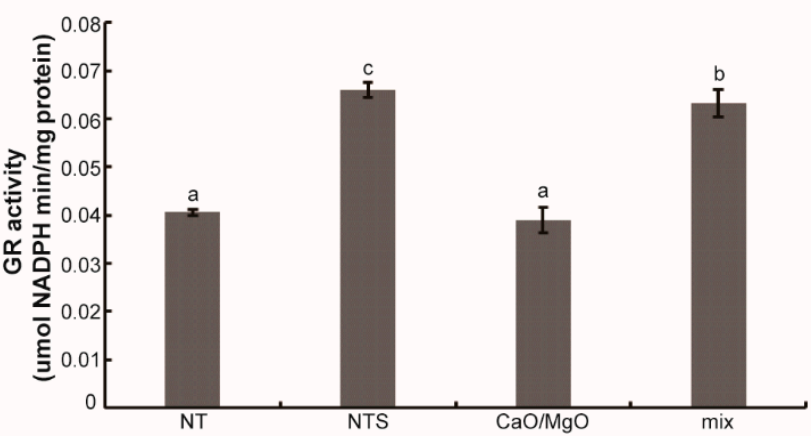

Figure 5. Effects of NTS, $\mathrm{CaO} / \mathrm{MgO}$, and mixed treatment on hydrogen peroxide content (A) change and SOD (B), CAT (C), and GR (D) activity in leaf lettuce leaves at one week after the fourth treatment. NT, nontreatment group; NTS, NTS treatment group; $\mathrm{CaO} / \mathrm{MgO}, \mathrm{CaO} / \mathrm{MgO}$ treatment group; mix, mixed (NTS, $\mathrm{CaO}$, and $\mathrm{MgO}$ ) treatment group. All experiments were repeated three times, and the error bars indicate standard deviation $((\mathbf{A}), n=12 ;(\mathbf{B}-\mathbf{D}), n=9)$. Different letters above bars indicate statistically significant differences as determined by one-way ANOVA $(p<0.05)$. 


\section{Discussion}

In this study, mineral-derived NTS induced the early growth-promoting effect of leaf lettuce and ultimately further improved the yield. The maximum yield of lettuce was observed in plants applied with a combination of NTS and Ca and Mg. This improvement in the yield of lettuce was observed to exert a great synergistic effect when applied to an appropriate amount of sulfur and micronutrients (Figure 1). We could not elucidate a clear mechanism for the causal relationship between the yield improvements, due to the combination of these three nutrients. However, it was observed that the expression level of the gene related to gibberellin biosynthesis increased in the mixed treatment group of these three nutrients (Figure 2B). Although there is no evidence that sulfur supply is directly involved in the synthesis of gibberellin, there is a possibility that it indirectly promotes the synthesis of growth-related hormones in terms of the role of sulfur assimilation in plants. In addition, the growth-promoting effect of NTS supply during the initial growth process in plant growth suggests that auxin is the result of controlling the growth of roots by regulating the cellular response to GA [48].

When plants cannot obtain sufficient sulfate, sulfate absorption is reduced, leading to reduced assimilation activity, affecting various metabolic processes [49,50]. This results in a decrease in the sulfur content in the plant tissue. Reduced sulfur content in plants inhibits sulfate assimilation (decreased cysteine and glutathione, reduced amounts of chlorophyll, reduced RNA and total protein, reduced lipids, nitrogen imbalance), reducing plant metabolism and growth rate [51]. The increase in chlorophyll content with the application of NTS and $\mathrm{CaO} / \mathrm{MgO}$ is shown in Figure 3. High levels of chlorophyll can increase light absorption. Previous studies have shown that sulfur deficiency adversely affects photosynthetic efficiency by reducing chlorophyll content $[52,53]$. On the other hand, it has been reported that the supply of sulfur fertilizer increases chlorophyll content [54]. The NTS and mixed treatment groups (NTS/CaO/MgO) showed a higher chlorophyll $\mathrm{a} / \mathrm{b}$ ratio value than the nontreatment group. Higher levels of chlorophyll $\mathrm{a} / \mathrm{b}$ ratio value contain less chlorophyll $b$ containing light-harvesting antenna; this indicates a lightadapted photosynthetic apparatus with more Calvin cycle enzymes and a higher capacity for electron transport [55].

The analysis of chlorophyll fluorescence parameters is an important approach for assessing the health and integrity of the photosynthetic system within the leaves; it also indicates stress [56,57]. The $\mathrm{F}_{\mathrm{v}} / \mathrm{F}_{\mathrm{m}}$ ratio estimates the maximum photochemical efficiency of PSII, detecting the loss of function of PSII reaction centers [58]. This ratio is proportional to the quantum yield of photochemistry, and in general, healthy plants have a value of $\mathrm{F}_{\mathrm{v}} / \mathrm{F}_{\mathrm{m}}$ between 0.75 and 0.85 [59]. When treating NTS directly to leaf lettuce, the $\mathrm{F}_{\mathrm{v}} / \mathrm{F}_{\mathrm{m}}$ ratio values were normal healthy plants; this means that the direct treatment of NTS is not toxic and stressful in leaf lettuce. We observed that the NTS application increased the $F_{0}$ and $F_{m}$ values. In general, sulfur deficiency or environmental stress leads to an increase in the $F_{0}$ and $F_{m}$ values and a decrease in $F_{v} / F_{m}[52,60]$. It has been reported that the treatment of nitrogen nutrients increases the chloroplast content and proportionally increases the $\mathrm{F}_{0}$ and $\mathrm{F}_{\mathrm{m}}$ values [61]; this is consistent with our results from the application of NTS.

Cysteine, an organic sulfur product, is used as a precursor to synthesize many sulfurcontaining metabolites with important biological functions, such as GSH and methionine. GSH is an important antioxidant substance $[10,62,63]$. Reduced GSH is involved in decomposing hydrogen peroxide into the water by GSH peroxidase. This reaction and dehydroascorbate (DHA) reductase (DHAR), GSH is converted into GSSG, and the changed GSSG is reduced to GSH by GR and NADPH. DHA is converted to ascorbate (ASC) by DHAR, and ASC is converted to monodehydroascorbate by ascorbate peroxidase (APX). In this process, $\mathrm{APX}$ converts $\mathrm{H}_{2} \mathrm{O}_{2}$ to $\mathrm{H}_{2} \mathrm{O}$. The ASC-GSH cycle plays an important role in the process of scavenging $\mathrm{H}_{2} \mathrm{O}_{2}$ [64]. It has been reported that the supply of sulfur $\left(\mathrm{MgSO}_{4}\right.$ and $\left.\mathrm{Na}_{2} \mathrm{SO} 4\right)$ lowers the level of $\mathrm{ROS}$ and increases the activity of antioxidant enzymes, including SOD, CAT, APX, and GR [65]. Direct NTS treatment in plant leaves also 
confirmed the same pattern of results (Figure 5), which did not reach the level of increased antioxidant enzyme activity caused by oxidative stress.

Our study shows that even a small amount of NTS supply of plant leaves has a growthpromoting effect comparable to that of soil fertilizer, suggesting that NTS provides great benefits to plant growth by more actively promoting sulfur assimilation. It also indicates that NTS exerts a greater synergistic effect when applied with micronutrients, such as Ca and $\mathrm{Mg}$.

\section{Conclusions}

In conclusion, NTS induced growth promotion and increased yield in leaf lettuce. Growth promotion in leaf lettuce is because improving the biosynthesis level of growthrelated hormones increases the chlorophyll content and antioxidant enzyme activity. This is due to the active sulfur assimilation that occurs because of the application of NTS. We propose NTS as a candidate substitute for soil fertilizer in the main sulfur supply of plants from these results.

Supplementary Materials: The following are available online at https:/ /www.mdpi.com/article/10 .3390/agriculture11080769/s1, Table S1: Primer sequences used for qRT-PCR analysis.

Author Contributions: Y.Y. and K.-J.J. designed the experiments. J.-C.P., N.S. and H.D.K. performed most of the experiments. D.Y.K., I.H.K. and S.W.B. assisted with the experiments and contributed to discussions. Y.Y., K.-J.J. and J.-C.P. analyzed the data. J.-C.P. wrote the manuscript. All authors have read and agreed to the published version of the manuscript.

Funding: This study was supported by Nara Bio Co., Ltd., Korea, in 2020.

Institutional Review Board Statement: Not applicable.

Informed Consent Statement: Not applicable.

Data Availability Statement: The data presented in this study are available on request from the corresponding author. The data are not publicly available due to privacy.

Conflicts of Interest: Hyoung Do Kim and Il Ho Kim are affiliated with Nara Bio Co., Ltd., which provided funding for this study and supplied nontoxic sulfur. The remaining authors declare that they have no competing interest.

\section{References}

1. Alix, A.; Capri, E. Chapter One-Modern agriculture in Europe and the role of pesticides. In Advances in Chemical Pollution, Environmental Management and Protection; Capri, E., Alix, A., Eds.; Elsevier: Amsterdam, The Netherlands, 2018 ; pp. 1-22.

2. Jallah, J.K.; Mulbah, C.K.; Kiazolu, J.S.; Frank, K.; Morris, M.Z. Efficient fertilizer use for increased crop production: The Liberia experience. Fertil. Res. 1991, 29, 55-64. [CrossRef]

3. Simonne, E.H.; Gazula, A.; Ozores-Hampton, M.; DeValerio, J.; Hochmuth, R.C. Localized application of fertilizers in vegetable crop production. In Advances in Research on Fertilization Management of Vegetable Crops; Tei, F.N.S., Benincasa, P., Eds.; Springer: Cham, Switzerland, 2017; pp. 149-181. [CrossRef]

4. Patnaik, P. Handbook of Environmental Analysis: Chemical Pollutants in Air, Water, Soil, and Solid Wastes, 2nd ed.; CRC Press: Boca Raton, FL, USA, 2010; p. 824. [CrossRef]

5. Ning, C.-C.; Gao, P.-D.; Wang, B.-Q.; Lin, W.-P.; Jiang, N.-H.; Cai, K.-Z. Impacts of chemical fertilizer reduction and organic amendments supplementation on soil nutrient, enzyme activity and heavy metal content. J. Integr. Agric. 2017, 16, 1819-1831. [CrossRef]

6. Prabakaran, G.; Vaithiyanathan, D.; Ganesan, M. Fuzzy decision support system for improving the crop productivity and efficient use of fertilizers. Comput. Electron. Agric. 2018, 150, 88-97. [CrossRef]

7. Nadarajan, S.; Sukumaran, S. Chapter 12-Chemistry and toxicology behind chemical fertilizers. In Controlled Release Fertilizers for Sustainable Agriculture; Lewu, F.B., Volova, T., Thomas, S., Rakhimol, K.R., Eds.; Academic Press: Cambridge, MA, USA, 2021; pp. 195-229. [CrossRef]

8. Shaji, H.; Chandran, V.; Mathew, L. Chapter 13-Organic fertilizers as a route to controlled release of nutrients. In Controlled Release Fertilizers for Sustainable Agriculture; Lewu, F.B., Volova, T., Thomas, S., Rakhimol, K.R., Eds.; Academic Press: Cambridge, MA, USA, 2021; pp. 231-245. [CrossRef]

9. Takahashi, H.; Kopriva, S.; Giordano, M.; Saito, K.; Hell, R. Sulfur Assimilation in Photosynthetic Organisms: Molecular Functions and Regulations of Transporters and Assimilatory Enzymes. Annu. Rev. Plant Biol. 2011, 62, 157-184. [CrossRef] 
10. Maruyama-Nakashita, A. Metabolic changes sustain the plant life in low-sulfur environments. Curr. Opin. Plant Biol. 2017, 39, 144-151. [CrossRef] [PubMed]

11. Yoshimoto, N.; Saito, K. S-Alk(en)ylcysteine sulfoxides in the genus Allium: Proposed biosynthesis, chemical conversion, and bioactivities. J. Exp. Bot. 2019, 70, 4123-4137. [CrossRef]

12. Nakai, Y.; Maruyama-Nakashita, A. Biosynthesis of Sulfur-Containing Small Biomolecules in Plants. Int. J. Mol. Sci. 2020, 21, 3470. [CrossRef]

13. Benning, C. Biosynthesis and Function of the Sulfolipid Sulfoquinovosyl Diacylglycerol. Annu. Rev. Plant Physiol. Plant Mol. Biol. 1998, 49, 53-75. [CrossRef]

14. Popper, Z.A.; Michel, G.; Hervé, C.; Domozych, D.S.; Willats, W.G.T.; Tuohy, M.G.; Kloareg, B.; Stengel, D.B. Evolution and Diversity of Plant Cell Walls: From Algae to Flowering Plants. Annu. Rev. Plant Biol. 2011, 62, 567-590. [CrossRef] [PubMed]

15. Hasanuzzaman, M.; Bhuyan, M.; Mahmud, J.A.; Nahar, K.; Mohsin, S.M.; Parvin, K.; Fujita, M. Interaction of sulfur with phytohormones and signaling molecules in conferring abiotic stress tolerance to plants. Plant Signal. Behav. 2018, 13, e1477905. [CrossRef]

16. Capaldi, F.R.; Gratão, P.L.; Reis, A.R.; Lima, L.W.; Azevedo, R.A. Sulfur Metabolism and Stress Defense Responses in Plants. Trop. Plant Biol. 2015, 8, 60-73. [CrossRef]

17. Henriet, C.; Aimé, D.; Térézol, M.; Kilandamoko, A.; Rossin, N.; Combes-Soia, L.; Labas, V.; Serre, R.F.; Prudent, M.; Kreplak, J.; et al. Water stress combined with sulfur deficiency in pea affects yield components but mitigates the effect of deficiency on seed globulin composition. J. Exp. Bot. 2019, 70, 4287-4304. [CrossRef] [PubMed]

18. Fuentes-Lara, L.O.; Medrano-Macías, J.; Pérez-Labrada, F.; Rivas-Martínez, E.N.; García-Enciso, E.L.; González-Morales, S.; Juárez-Maldonado, A.; Rincón-Sánchez, F.; Benavides-Mendoza, A. From Elemental Sulfur to Hydrogen Sulfide in Agricultural Soils and Plants. Molecules 2019, 24, 2282. [CrossRef] [PubMed]

19. Yu, Z.; Juhasz, A.; Islam, S.; Diepeveen, D.; Zhang, J.; Wang, P.; Ma, W. Impact of mid-season sulphur deficiency on wheat nitrogen metabolism and biosynthesis of grain protein. Sci. Rep. 2018, 8, 2499. [CrossRef]

20. Anderson, J.W.; Fitzgerald, M.A. Physiological and metabolic origin of sulphur for the synthesis of seed storage proteins. J. Plant Physiol. 2001, 158, 447-456. [CrossRef]

21. Agrawal, H.P.; Mishra, A.K. Sulphur nutrition of soybean. Commun. Soil Sci. Plant Anal. 1994, 25, 1303-1312. [CrossRef]

22. Zhao, Y.; Bi, D.; Zhao, Q.; Liu, C.; Hu, Z. Physiological and ecological effects of sulfur fertilization on soybean. Ying Yong Sheng Tai Хие Bao 2006, 17, 2376-2380.

23. Scherer, H.W. Sulphur in crop production-Invited paper. Eur. J. Agron. 2001, 14, 81-111. [CrossRef]

24. Koh, E.; Surh, J. Influence of Sulfur Fertilization on the Antioxidant Activities of Onion Juices Prepared by Thermal Treatment. Prev. Nutr. Food Sci. 2016, 21, 160-164. [CrossRef]

25. Caron, J.M.; Bannon, M.; Rosshirt, L.; Luis, J.; Monteagudo, L.; Caron, J.M.; Sternstein, G.M. Methyl sulfone induces loss of metastatic properties and reemergence of normal phenotypes in a metastatic cloudman S-91 (M3) murine melanoma cell line. PLoS ONE 2010, 5, e11788. [CrossRef]

26. Kang, D.Y.; Sp, N.; Jo, E.S.; Kim, H.D.; Kim, I.H.; Bae, S.W.; Jang, K.J.; Yang, Y.M. Nontoxic sulfur enhances growth hormone signaling through the JAK2/STAT5b/IGF1 pathway in C2C12 cells. Int. J. Mol. Med. 2020, 45, 931-938. [CrossRef] [PubMed]

27. Lim, E.J.; Hong, D.Y.; Park, J.H.; Joung, Y.H.; Darvin, P.; Kim, S.Y.; Na, Y.M.; Hwang, T.S.; Ye, S.K.; Moon, E.S.; et al. Methylsulfonylmethane suppresses breast cancer growth by down-regulating STAT3 and STAT5b pathways. PLoS ONE 2012, 7, e33361. [CrossRef] [PubMed]

28. Joung, Y.H.; Darvin, P.; Kang, D.Y.; Sp, N.; Byun, H.J.; Lee, C.H.; Lee, H.K.; Yang, Y.M. Methylsulfonylmethane Inhibits RANKLInduced Osteoclastogenesis in BMMs by Suppressing NF-kappaB and STAT3 Activities. PLoS ONE 2016, 11, e0159891. [CrossRef] [PubMed]

29. Sreekantan Preetha, N.; Kang, D.Y.; Darvin, P.; Kim, D.N.; Joung, Y.H.; Kim, S.Y.; Cho, K.H.; Do, C.H.; Park, K.D.; Lee, J.-H.; et al. Induction of in vitro ketosis condition and suppression using methylsulfonylmethane by altering ANGPTL3 expression through STAT5b signaling mechanism. Anim. Cells Syst. 2015, 19, 30-38. [CrossRef]

30. Miller, L.E. Methylsulfonylmethane decreases inflammatory response to tumor necrosis factor- $\alpha$ in cardiac cells. Am. J. Cardiovasc. Dis. 2018, 8, 31-38. [PubMed]

31. Kang, D.Y.; Sp, N.; Jo, E.S.; Rugamba, A.; Kim, H.D.; Kim, I.H.; Park, J.C.; Bae, S.W.; Jang, K.J.; Yang, Y.M. Non-toxic sulfur inhibits LPS-induced inflammation by regulating TLR-4 and JAK2/STAT3 through IL-6 signaling. Mol. Med. Rep. 2021, 24, 485. [CrossRef] [PubMed]

32. Jo, E.S.; Sp, N.; Kang, D.Y.; Rugamba, A.; Kim, I.H.; Bae, S.W.; Liu, Q.; Jang, K.-J.; Yang, Y.M. Sulfur Compounds Inhibit High Glucose-Induced Inflammation by Regulating NF-kB Signaling in Human Monocytes. Molecules 2020, 25, 2342. [CrossRef] [PubMed]

33. Sp, N.; Kang, D.Y.; Kim, H.D.; Rugamba, A.; Jo, E.S.; Park, J.-C.; Bae, S.W.; Lee, J.-M.; Jang, K.-J. Natural Sulfurs Inhibit LPS-Induced Inflammatory Responses through NF-kB Signaling in CCD-986Sk Skin Fibroblasts. Life 2021, 11, 427. [CrossRef]

34. Gilbert, F.A. The Place of Sulfur in Plant Nutrition. Bot. Rev. 1951, 17, 671-691. [CrossRef]

35. Palmer, R.V.; Zhao, F.J.; McGrath, S.P.; Hawkesford, M.J. Sulphur supply and the optimisation of the yield of wheat. In Plant Nutrition: Food Security and Sustainability of Agro-Ecosystems through Basic and Applied Research; Horst, W.J., Schenk, M.K., Bürkert, 
A., Claassen, N., Flessa, H., Frommer, W.B., Goldbach, H., Olfs, H.W., Römheld, V., Sattelmacher, B., et al., Eds.; Springer: Dordrecht, The Netherlands, 2001; pp. 836-837. [CrossRef]

36. Messick, D. Correcting Sulphur Deficiency for Higher Productivity. FAI Seminar, New Delhi, India, December 5-7, The Sulphur Institute (TSI), Washington, United States. 2007. Available online: https:/ / www.yumpu.com/en/document/view/30788633 / correcting-sulphur-deficiency-for-higher-productivity (accessed on 12 August 2021).

37. Dougher, T.A.; Bugbee, B. Differences in the Response of Wheat, Soybean and Lettuce to Reduced Blue Radiation. Photochem. Photobiol. 2001, 73, 199-207. [CrossRef]

38. Kim, H.-H.; Goins, G.D.; Wheeler, R.M.; Sager, J.C. Green-light supplementation for enhanced lettuce growth under red-and blue-light-emitting diodes. HortScience 2004, 39, 1617-1622. [CrossRef] [PubMed]

39. Livak, K.J.; Schmittgen, T.D. Analysis of Relative Gene Expression Data Using Real-Time Quantitative PCR and the $2^{-\Delta \Delta C T}$ Method. Methods 2001, 25, 402-408. [CrossRef]

40. Lichtenthaler, H.K.; Wellburn, A.R. Determinations of total carotenoids and chlorophylls a and b of leaf extracts in different solvents. Biochem. Soc. Trans. 1983, 11, 591-592. [CrossRef]

41. Kalaji, H.M.; Schansker, G.; Ladle, R.J.; Goltsev, V.; Bosa, K.; Allakhverdiev, S.I.; Brestic, M.; Bussotti, F.; Calatayud, A.; Dabrowski, P.; et al. Frequently asked questions about in vivo chlorophyll fluorescence: Practical issues. Photosynth. Res. 2014, 122, 121-158. [CrossRef] [PubMed]

42. Górnik, K.; Lahuta, L.B. Application of phytohormones during seed hydropriming and heat shock treatment on sunflower (Helianthus annuus L.) chilling resistance and changes in soluble carbohydrates. Acta Physiol. Plant. 2017, 39, 118. [CrossRef]

43. Alexieva, V.; Sergiev, I.; Mapelli, S.; Karanov, E. The effect of drought and ultraviolet radiation on growth and stress markers in pea and wheat. Plant Cell Environ. 2001, 24, 1337-1344. [CrossRef]

44. Bradford, M.M. A rapid and sensitive method for the quantitation of microgram quantities of protein utilizing the principle of protein-dye binding. Anal. Biochem. 1976, 72, 248-254. [CrossRef]

45. Beyer, W.F.; Fridovich, I. Assaying for superoxide dismutase activity: Some large consequences of minor changes in conditions. Anal. Biochem. 1987, 161, 559-566. [CrossRef]

46. Aebi, H. Catalase. In Methods of Enzymatic Analysis, 2nd ed.; Bergmeyer, H.U., Ed.; Academic Press: Cambridge, MA, USA, 1974; pp. 673-684. [CrossRef]

47. Rao, M.V.; Paliyath, G.; Ormrod, D.P. Ultraviolet-B- and ozone-induced biochemical changes in antioxidant enzymes of Arabidopsis thaliana. Plant Physiol. 1996, 110, 125-136. [CrossRef] [PubMed]

48. Fu, X.; Harberd, N.P. Auxin promotes Arabidopsis root growth by modulating gibberellin response. Nature 2003, 421, 740-743. [CrossRef]

49. Hirai, M.Y.; Fujiwara, T.; Awazuhara, M.; Kimura, T.; Noji, M.; Saito, K. Global expression profiling of sulfur-starved Arabidopsis by DNA macroarray reveals the role of $O$-acetyl-L-serine as a general regulator of gene expression in response to sulfur nutrition. Plant J. 2003, 33, 651-663. [CrossRef]

50. Hirai, M.Y.; Saito, K. Post-genomics approaches for the elucidation of plant adaptive mechanisms to sulphur deficiency. J. Exp. Bot. 2004, 55, 1871-1879. [CrossRef] [PubMed]

51. Nikiforova, V.J.; Kopka, J.; Tolstikov, V.; Fiehn, O.; Hopkins, L.; Hawkesford, M.J.; Hesse, H.; Hoefgen, R. Systems rebalancing of metabolism in response to sulfur deprivation, as revealed by metabolome analysis of Arabidopsis plants. Plant Physiol. 2005, 138, 304-318. [CrossRef] [PubMed]

52. Terry, N. Effects of sulfur on the photosynthesis of intact leaves and isolated chloroplasts of sugar beets. Plant Physiol. 1976, 57, 477-479. [CrossRef] [PubMed]

53. Resurreccion, A.P.; Makino, A.; Bennett, J.; Mae, T. Effects of sulfur nutrition on the growth and photosynthesis of rice. Soil Sci. Plant Nutr. 2001, 47, 611-620. [CrossRef]

54. Skudra, I.; Ruza, A. Effect of Nitrogen and Sulphur Fertilization on Chlorophyll Content in Winter Wheat. Rural Sustain. Res. 2017, 37, 29-37. [CrossRef]

55. Evans, J.R. Acclimation by the thylakoid membranes to growth irradiance and the partitioning of nitrogen between soluble and thylakoid proteins. Funct. Plant Biol. 1988, 15, 93-106. [CrossRef]

56. Maxwell, K.; Johnson, G.N. Chlorophyll fluorescence-A practical guide. J. Exp. Bot. 2000, 51, 659-668. [CrossRef] [PubMed]

57. Lichtenthaler, H.K.; Buschmann, C.; Knapp, M. How to correctly determine the different chlorophyll fluorescence parameters and the chlorophyll fluorescence decrease ratio RFd of leaves with the PAM fluorometer. Photosynthetica 2005, 43, 379-393. [CrossRef]

58. Öquist, G.; Chow, W.S.; Anderson, J.M. Photoinhibition of photosynthesis represents a mechanism for the long-term regulation of photosystem II. Planta 1992, 186, 450-460. [CrossRef] [PubMed]

59. Kitajima, M.; Butler, W.L. Quenching of chlorophyll fluorescence and primary photochemistry in chloroplasts by dibromothymoquinone. Biochim. Biophys. Acta 1975, 376, 105-115. [CrossRef]

60. Kalaji, H.M.; Jajoo, A.; Oukarroum, A.; Brestic, M.; Zivcak, M.; Samborska, I.A.; Cetner, M.D.; Eukasik, I.; Goltsev, V.; Ladle, R.J. Chlorophyll a fluorescence as a tool to monitor physiological status of plants under abiotic stress conditions. Acta Physiol. Plant 2016, 38, 102. [CrossRef]

61. Mauromicale, G.; Ierna, A.; Marchese, M. Chlorophyll fluorescence and chlorophyll content in field-grown potato as affected by nitrogen supply, genotype, and plant age. Photosynthetica 2006, 44, 76. [CrossRef] 
62. Aarabi, F.; Naake, T.; Fernie, A.R.; Hoefgen, R. Coordinating sulfur pools under sulfate deprivation. Trends Plant Sci. 2020, 25, 1227-1239. [CrossRef] [PubMed]

63. Chan, K.X.; Phua, S.Y.; Van Breusegem, F. Secondary sulfur metabolism in cellular signalling and oxidative stress responses. J. Exp. Bot. 2019, 70, 4237-4250. [CrossRef]

64. Waszczak, C.; Carmody, M.; Kangasjärvi, J. Reactive Oxygen Species in Plant Signaling. Annu. Rev. Plant. Biol. 2018, 69, 209-236. [CrossRef]

65. Chandra, N.; Pandey, N. Influence of Sulfur Induced Stress on Oxidative Status and Antioxidative Machinery in Leaves of Allium cepa L. Int. Sch. Res. Not. 2014, 2014, 568081. [CrossRef] 